\title{
Preventive Penalisation in China: Background, Adverse Impacts and Judicial Restriction
}

\section{Zhenjie ZHOU ${ }^{1}$}

\begin{abstract}
Recent criminal law reforms in China show a noticeable preventive character by criminalising preparatory activities, lowering conviction threshold and imposing crime prevention obligation on legal persons, especially internet service providers. Timely preventive penalisation is necessary because it responds to a requirement of modern society to prevent invisible yet destructive risks in almost every corner of industrial activities. Meanwhile, preventive penalisation puts criminal law and citizens in danger too, because punishing formally unlawful conducts that cause no harm to society leads to not only injustice in criminal justice but also ineffective allocation of precious resources. Chinese legislation gives enough space and choices to judiciary to prevent adverse impact of preventive penalisation in practice. Unfortunately, the absence of a common recognition of this obligation and collective action shows that there is still a long way to go before establishment of a check and balance mechanism between seemingly unstoppable preventive penalisation and criminal justice.
\end{abstract}

Keywords: preventive penalisation, fundamental principles of criminal law, symbolic legislation, check and balance

\section{Introduction}

Along with gradually entering the risk society advocated by Ulrich Beck after the 1970s, we have been confronted with unprecedented risks created by such modern factors as terrorist attacks, globalisation and environmental pollution. Consequently, the fear stemming from these risks and the anxiety as to how to successfully cope with them slowly but firmly seep into criminal laws adopted especially after the 2000s in many countries. Mainly intended to prevent risks, these laws share a common character of sanctioning activities that may cause harm to society, no matter how thin its possibility is, and whether they are substantially dangerous. This phenomenon is entitled 'preventive penalisation' in China and has become a public concern and a new

Prof. Zhenjie ZHOU PhD, Professor of Anhui Normal University and Beijing Normal University

https://orcid.org/0000-0002-5791-1556; 11112010132@bnu.edu.cn 
target of academic criticism because it potentially unduly infringes on citizens' rights and shakes fundamental principles of criminal law. ${ }^{2}$

The trend of preventive penalisation is very likely to continue in a foreseeable future in China because, as can be inferred from the title of 'a tool for four modernizations', 3 the utilitarian value of criminal law as a control tool is traditionally more stressed than others such as protection. Meanwhile, China is still in a rapid transition process and must face unknown changes and risks. ${ }^{4}$ Therefore, it is necessary and urgent to answer the question how to restrict the adverse effects of preventive penalisation.

\section{The preventive character of criminal law reforms since 1997}

China adopted the Criminal Law of People's Republic of China in 1979, the first penal code after its foundation in 1949, and then enacted a comprehensive Amendment to it in 1997 (hereinafter, the 1997 Criminal Law) - which is actually a compilation of the first penal code, special criminal laws and supplementary criminal provisions in administrative, social and economic laws adopted since the beginning of 1980s - to deal with political and social changes mainly caused by the reform and opening-up policy. Since 1997, China's National People's Congress (hereinafter, the NPC) has enacted ten amendments to the 1997 Criminal Law and a special criminal law tilted Decision Concerning Punishment of Criminal Offenses Involving Fraudulent Purchase, Evasion and Illegal Trading of Foreign Exchange in 1999. All these reforms demonstrate a noticeable preventive character.

In the first place, regulatory crime accounts for more than 90 percent of newly created crimes. The NPC has created 55 new crimes since the adoption of the 1997 Criminal Law and thereby increased the total number of crimes from 414 in 1997 to 469 in 2019. As can be easily seen in Figure 1, although these new crimes can be found in seven of ten Chapters in the Special Part of the 1997 Criminal Law, only six are in Chapter Four, 'Crimes of Infringing on the Right of the Person and Citizens' Democratic Rights', such as murder, intentional assaults, kidnap, rape and unlawful imprisonment, while nearly 90 per cent (49) are the so-called regulatory crimes. As is well known, a regulatory crime is usually not considered a true crime ${ }^{5}$ and is designed to prevent a harm or a risk from being caused by imposing a duty to or not to carry out

\footnotetext{
For example R. G. He, 'Yufangxing Fankongxingshilifa Sikao [On Preventive Counter-Terrorism Criminal Legislation]', Chinese Legal Science 3 (2016), 145-163; Y. H. Liu, 'Xiangzhengxing Lifa dui Xingfa Gongneng de Sunhuai' [Damage of Symbolic Legislation on Functions of Criminal Law], Politics and Law 3 (2018), 35-49; C. Q. Mei and J. Li, 'Woguo Fankong Xingfa Lifa Yufngxing Mianxiang Jianshi [Critical Comments on China's Counter-Terrorism]', Legal Science 1 (2018), 48-58.

3 M. X. Gao and K. C. Ma, Xingfaxue [Criminal Law] (Beijing: High Education Press and Law Press, 2011), 8.

4 R. W. Liu and X. P. Jiao, 'Fengxian Xingfa de Shehui Jichu' [Social Foundation of Risk Criminal Law], Journal China University of Political Science and Law 3 (2014), 45-56.

5 For example M. R. Huang, 'Yelun Xingzhengfan de Xingzhi jiqi dui Xingzhengxingfa Dingwei De Yingxiang' [Re-discussion on the Nature of Administrative Crime and its Influence on the Status of Administrative Criminal Law], Modern Law Science 5 (2004), 81-87.
} 
a conduct which can potentially cause harm or risk and usually does not require any causation and consequence for conviction.

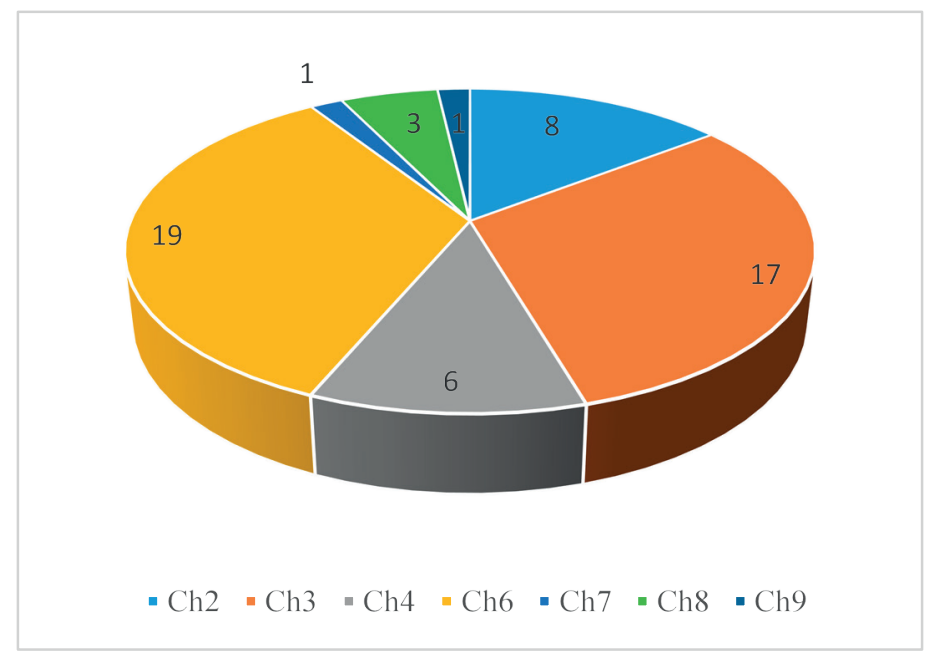

Figure 1: Distribution of new crimes. Source: Amendments I-X to the Criminal Law of P.R.C.

Secondly, conviction thresholds of a considerably big number of crimes have been lowered. For example, the Eighth Amendment to the 1997 Criminal Law (hereinafter, the Eight Amendment) that became effective as of 1 May 2011 changed the notion of crime in article 109 of the 1997 Criminal Law from a crime of consequence to a crime of conduct by deleting the requirement of 'seriously endangered the state security', and the same Amendment turned the notion of crime in article 141 of the same law from a crime of danger to a crime of conduct by deleting the constitution element of 'being dangerous enough to cause serious bodily harm'. Such changes are obviously intended to prevent possible harms by imposing heavier liability on conducts that may cause them than before.

Thirdly, corporate criminal liability was continuously extended, and the duty of crime prevention was even imposed on corporations. Corporate criminal liability was not accepted by Chinese legislation until 1988, when the amended Customs Law of People's Republic of China directly imposed criminal liability on commercial organisations for smuggling, mainly due to the heavy influence of liability principle of continental law countries stressing moral blameworthiness and individualism on Chinese theoretical and legislative professionals and the implementation of planned economy system. Then, corporate criminal liability was quickly adopted into numerous administrative and economic laws in the first half of the 1990s. Consequently, the 1997 Criminal Law not only provides 136 specific corporate crimes in nine chapters of its Special Part 
but also added two articles providing corporate criminal liability and principles of punishing legal persons in its General Part. ${ }^{6}$

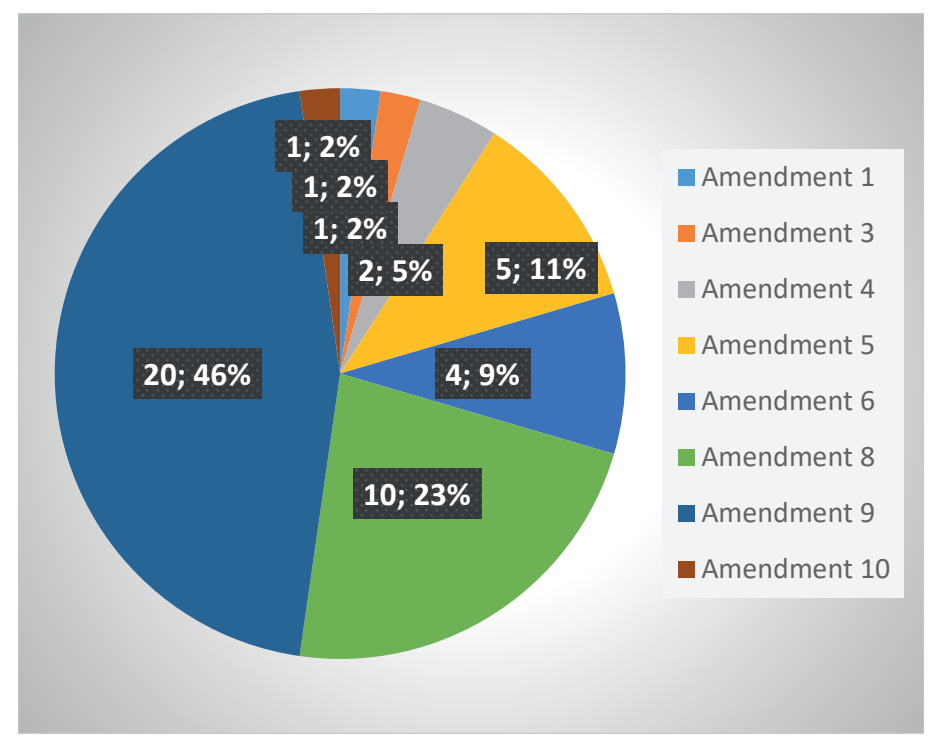

Figure 2: Number of new corporate crimes in the Amendments to the

Criminal Law of P.R.C. Source: compiled by the author based on Amendments I-X to the Criminal Law of P.R.C.

Corporate criminal liability was rapidly extended since then. When the 1997 Criminal Law was adopted, a corporation could be held criminally liable for 146 crimes. As Figure 2 shows, eight of the ten amendments adopted in 1999 to 2018 created 44 new corporate crimes; most importantly, the eighth and the ninth one, respectively, created 10 and 20 crimes, accounting for more than 68 per cent of the total number. Meanwhile, a corporation can now be held culpable for its failure to fulfill the duty of preventing certain offences. For example, article 286a added by the Ninth Amendment to the 1997 Criminal Law (hereinafter, the Ninth Amendment) imposes on network service providers a duty to perform information network security management and makes the failure to fulfill this obligation a crime punishable by three years imprisonment for natural persons and unlimited fine for legal persons. Although Chinese legislators tried to reduce the public concern that article 286a may unduly impair the enthusiasm of network service providers to innovate information technologies and may hinder development, by inserting a restrictive constitution element that a network service provider will be punished only when it is ordered by a regulator authority yet refused to take correction measures, the fact that key terms in the article such as regulatory

For a detailed history of corporate criminal liability, see Z. J. Zhou, Bijiaofa Shiye zhong de Danwei Fanzui [Comparative Studies on Corporate Crime] (Beijing: China Public Security University Press, 2012), 22-28. 
authority and illegal information have not been clearly defined so far implies that the application of article is still unpredictable to a degree. ${ }^{7}$

Fourthly, although article 22 has penalised all preparatory activities in principle, ${ }^{8}$ certain preparatory activities have been penalised as independent crimes due to the fact that the risks they may cause are so severe that giving them a relatively light punishment or even immunity creates little, if any, deterrence. ${ }^{9}$ For example, article 287a of the 1997 Criminal Law added by the Ninth Amendment penalised the conduct of establishing a website or a communication group to commit fraud, or teaching about how to commit a crime, produce or sell any prohibited article or commit any other illegal or criminal activity. Another example is article 120b of the same law, which directly made preparing weapons, hazardous items or other tools for carrying out terrorist activities or other criminal activities an individual crime with a maximum punishment of five years imprisonment. Meanwhile, Chinese legislature took a similar approach to penalise activities of accessories. Considering the authoritative interpretation on the constitution of joint crime in article 25 of the 1997 Criminal Law, which insists that it is necessary for joint offenders to communicate with each other and thereby form a common intention, ${ }^{10}$ and which makes it impossible to punish those who objectively 'assisted' a principal without communicating with the latter, especially in the case of cybercrime, the Ninth Amendment created the crime of assisting information and internet crimes, with the intention to punish those who provide internet access, server custody, network storage, communication transmission or any other technical support, or provide advertising, payment settlement or any other assistance for a crime, whether they communicate with other parties of the crime or not.

Finally, punishments for certain crimes were made harsher. For example, the Sixth Amendment to the 1997 Criminal Law (hereinafter, the Sixth Amendment), adopted in June 2006, increased the maximum punishment in article 134 of the 1997 Criminal Law from three years to five years in the case where any serious casualty or any other serious consequences are caused, and from seven years to 15 years in the case where circumstances are extremely severe. For another example, the Ninth amendment increased the maximum punishment in article 322 of the same law from one year imprisonment to three years imprisonment by adding a second part to the article providing that whoever secretly crosses China's frontier (border) for the purpose of joining a terrorist organisation, receiving training in terrorist activities or conducting terrorist activities, shall be sentenced to imprisonment of not less than one year but not more than three years in addition to a fine.

\footnotetext{
W. H. Wang, 'Jubu Lvxing Xinxi Wangluo Jianguan Yiwu Zui Shiyong Fenxi' [Analysis of the Crime of Refusing to Fulfill Network Security Management Obligation], People's Procuratorate 6 (2016), 24-27.

8 According to the article, an offender who prepares for a crime may, in comparison with one who completes the crime, be given a lighter or mitigated punishment or be exempted from punishment.

9 L. L. Gao, 'Zhunbei Shishi Kongbuhuodong Zui-Yi Yubeixingwei Shixinghua wei Shijiao de Hongguanjiegou' [Crime of Preparation for Terrorism: Macroscopic Interpretation in the Perspective of Implementation Behaviors], Legal Forum 2 (2018), 152-161.

10 Gao and Ma, Xingfaxue (2011), 163.
} 
As far as punishment is concerned, the creation of the Chinese version of life without parole (LWOP) may be the best example of preventive penalisation in China. The Ninth Amendment, intending to increase deterrence against corruption and bribery, authorises the people's court to sentence convicts condemned to suspended death sentence to life imprisonment without any possibility of commutation or parole in light of the circumstances of the crime committed upon expiration of the two-year suspended period in cases of graft or accepting bribes, according to article 382 and article 385 of the 1997 Criminal Law. Meanwhile, LWOP must be used resolutely ${ }^{11}$ if legal requirements are met according to judges in the Supreme People's Court of People's Republic of China (hereinafter: the SPC). Although strongly criticised, ${ }^{12}$ LWOP has also obtained strong support in academia and the public for its precepted deterrence effect.

\section{The background of preventive penalisation in China}

Why did China strengthen preventive penalisation in recent decades? This question should be answered at macro and micro levels. At macro level, the traditional image of criminal punishment as the most powerful tool of social control, and the transition China is experiencing, especially rapid economic development and the entry into risk society, undoubtedly play an important role. At micro level, increasing threat of certain crimes - such as corruption - and political concern over them should be mentioned here.

\subsection{Macro background of preventive penalisation}

\subsubsection{Rapid economic development and its influence}

At macro level, rapid economic development should be mentioned first, for two reasons. One is that economic base of a society determines its superstructures, as classic Chinese political economy or politics textbooks read. Chinese economy has been on rapid increase in past decades. As Figure 3 shows, China's GDP increased from RMB 18.5 trillion in 2005 to RMB 90 trillion in 2018. Such a tremendous economic change inevitably affected the superstructure of Chinese society, and criminal law, one of the most crucial laws over society. The other is that economic increase itself has two sides. While bringing us wealth and convenience, it leads for example to environmental pollution, damages natural and ecological system and may be utilised by transnational

11 X. D. Pei et alii, 'Guanyu Bali Tanwu Huilu Xingshi Anjian Ruogan Wenti de Jieshi Lijie yu Shiyong' [Understanding and Application of Interpretation on Legal Issues regarding Handling Criminal Cases of Corruption and Bribery], People's Justice 19 (2016), 17-20.

12 For example Y. H. Wu, 'Lun Zuowei Sixing Tidai Cuoshi de Zhongshenjianjin' [LWOP as An Alternative to the Death Penalty], Global Law Review 1 (2017), 131-148; J. Hu, 'Normative Interpretation and Theoretic Reflection on LWOP', Journal of Southwestern University of Political Science and Law 6 (2016), 57-64. 
criminal groups for laundering money. Food safety related crime might be an excellent example here as it not only affects public health but also political stability.

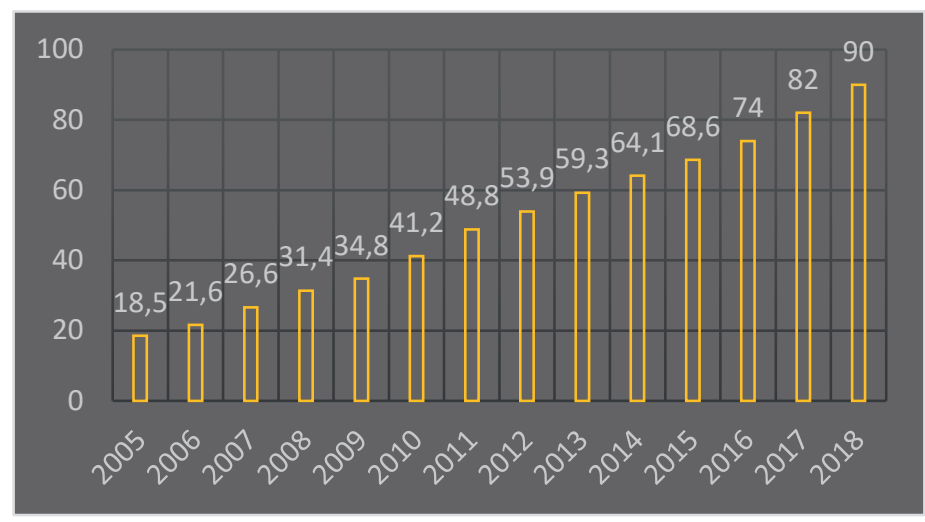

Figure 3: China's GDP (trillions). Source: China Statistic Yearbooks (2006-2019)

An old Chinese saying goes that people regard enough food as their heaven. However, this heaven has been proven 'contaminated' by a big number of food safety scandals in the past two decades, such as the Sanlu infant formula scandal in 2008, in which contaminated milk powder resulted in more than 30 deaths and thousands of injuries of infants, ${ }^{13}$ and the Shanghai Husi food scandal in 2014, in which a supplier to leading fast food brands including McDonald's, KFC and Pizza Hut was charged with using expired meat in their products. ${ }^{14}$ What is more terrible is that problems were found from every link in the production chain. As a consequence, food safety became one of the top concerns in China. According to an annual survey conducted by China Youth Daily in March 2015, more than 77 per cent of interviewees chose food safety out of a long list of 'quality of life' issues - including housing and the environment - as their top concern. ${ }^{15}$ Public concern attracted political attention and soon came legislative reforms in turn, including criminal law reforms. For example, The Eighth Amendment, first, extended the coverage of article 143 of the 1997 Criminal Law by replacing 'hygiene standards' with 'food safety standards' and penalising the conduct of 'producing or selling food that potentially causes any other serious food-borne disease' beyond serious food poisoning accident; secondly, in article 144 of the same law, it eliminated the limits on the amount of criminal fine, in order to give judges greater discretion than before, and added article 408a to the same law, creating a new crime of

\footnotetext{
For example Zhou, Bijiaofa, 104.

14 J. Chen, 'Shanghai Fuxi Shijian Xiangguan Gongsi Renfa 2428.5 Wan' [Company Fined 24.285 Million in Shanghai Fuxi Scandal], Sina, December 6, 2019. Available: http://news.sina.com.cn/sf/news/2016-10-03/doc-ifxwkzyh4151795. shtml (26. 11. 2020.)

15 See 'Food safety top concern in China', Xinhua News, June 2015. Available: www.chinadaily.com.cn/business/2015-06/19/content_21050938.htm (08.12. 2019.)
} 
failure of a state functionary with food safety supervision and management functions to fulfill his or her duties properly, punishable by 15 years imprisonment.

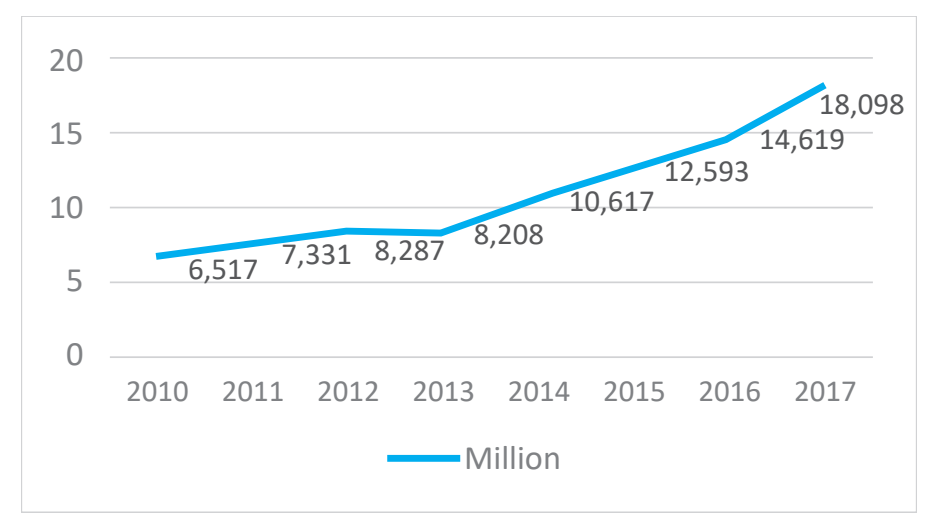

Figure 4: Number of legal persons in China (2010-2017). Source: China Statistic Yearbooks (2011-2018)

Another example suitable for proving the influence of economic development on criminal law is the quick extension of corporate criminal liability, especially after 2010. Rapid economic development naturally led to rapid increase in the number of legal persons, the subjects of market activities. As Figure 4 shows, the number of enterprises with the status of legal person has been on quick increase even after the 2010s in China, and almost tripled in 2017 (180,980,000) compared to 2010. The increase, while demonstrating the vigour and energy of Chinese economic development, implies that more and more actors driven by the desire to gain profits even at the cost of being unlawful are entering market - which had been proven one of the major sources of corporate illegality in the 1980 s in China $^{16}$-, and causing dangers and harms serious enough for criminal law to intervene.

\subsubsection{Risk society and its influence}

Another factor especially worthy of being mentioned at macro level is the gradual transition of China into the so-called risk society after the 1990 s. ${ }^{17}$ Risk society can of course be considered a consequence of industrialisation and therefore thought of as an advanced stage of industrial society ${ }^{18}$ but it has demonstrated characteristics unseen before. For example, most risks at this stage can be said to be systemic and carefully balanced by specialised individuals or organisations, and a harmful consequence may be caused by 'lawful' processes. What is more important, some risks cannot even be

Zhou, Bijiaofa, 22-24.

Liu and Jiao, 'Fengxian Xingfa'.

18 U. Beck, 'From Industrial Society of Risk Society Part I', Marxism and Reality 3 (2003). 
recognised until tragedies fall onto us, because they only exist in complicated processes, chemical formulae or seemingly perfect daily management, as the 2004 Anhui Fuyang milk scandal, the 2010 Dalian oil pipe explosion incident, the 2014 Jiangsu Kunshan explosion incident and the 2017 Tianjin fire incident have proven. ${ }^{19}$

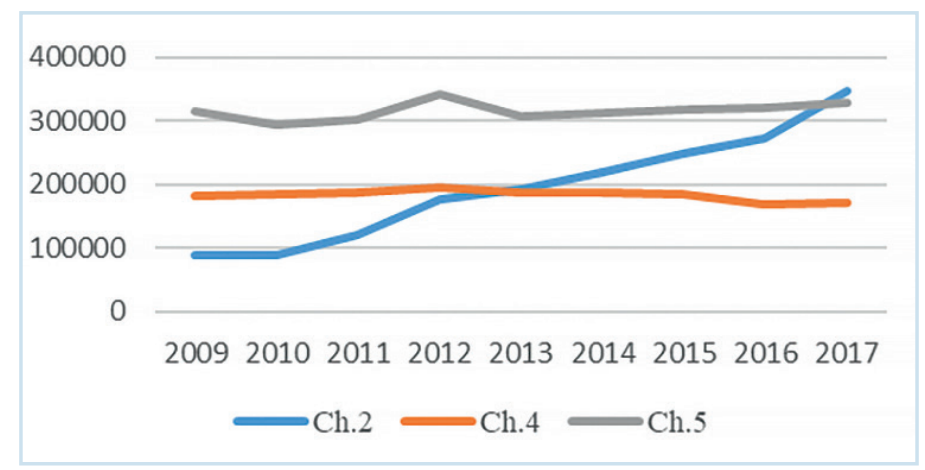

Figure 5: Criminal Cases of Ch.2, Ch.4 and Ch.5 registered at first instance trial (2009-2017). Source: China Statistic Yearbooks (2010-2018)

Therefore, as Figure 5 shows, criminal cases of Chapter 2 of the Special Part of the 1997 Criminal Law, Crimes of Endangering Public Security, were on sharp increase at first instance trials between 2009 and 2017, while those of Chapter IV, Crimes of Infringing on the Rights of the Person and Citizens' Democratic Rights, remained stable or even decreased. In other words, although such crimes that are traditionally considered serious, as murder and rape, must be closely watched, those that put the whole society in danger and instability are worth more attention from the perspectives of collective security, social development and political stability.

However, as mentioned above, risks at current stage are hard to identify and predict, and their harmful consequences are almost impossible to prevent. Consequently, Chinese legislators are paying more attention to regulating activities and conducts that potentially create such risks than preventing and punishing actual risks and harms. Meanwhile, the fact that most of such risks result from economic activities makes it necessary to regulate conducts of disturbing market economy order in Chapter 3 of the Special Part of the 1997 Criminal Law, and this is why eight of 55 newly created crimes are in Chapter 7 and 17 in Chapter 3, accounting for more than 45 per cent in total, and conviction thresholds of many crimes in the two chapters have been lowered.

19 Z. J. Zhou, 'Cong Gongyeshehui dao Fengxianshehui', WIAS Research Bulletin 11 (2019), 17-30. 


\subsection{Micro background of preventive penalisation}

Undoubtedly, many specific factors have contributed to the current of preventive penalisation in China. Meanwhile, threats posed by terrorism, corruption and internet are especially worthy of being mentioned here and investigated regarding the contents of the Amendments to the 1997 Criminal Law.

\subsubsection{Terrorism}

Terrorism was not considered a serious threat by the highest decision makers until the 1990s in China, because terrorist activity was barely seen or even heard then. Therefore, the 1997 Criminal Law provided only one terrorism crime - in article 120 of its Special Part at the time of adoption -, namely, forming, leading and positively participating in a terrorist organisation, although terrorist threat had begun to rise, especially in conflicting zones such as Afghanistan and Chechnya. ${ }^{20}$

The 9/11 terrorist attack in 2001 shocked the world. Alarmed Chinese legislators quickly adopted the Amendment III to the 1997 Criminal Law (the Third Amendment) on 29 December 2001 and created three new crimes, namely, providing fund to any terrorist organisation or individual who engages in terrorism (article 120a), and spreading hoaxes of dangerous substances, fabricating terrorist information or intentionally disseminating fabricated terrorist information (article 291a of the 1997 Criminal Law). However, it should be admitted that terrorism would still be far away at least in average Chinese's mind, were it not for the 7/5 terrorist attacks in 2009 in Urumqi, Xinjiang Uygur Autonomous Region of China, which resulted in more than 100 deaths and about 1,000 injuries, not to say the large amount of property loss. Since then, terrorist activities in China not only increased but also commenced to be more organised and international, partly due to the rising influence of international terror groups, especially the Islamic State established in 2013. It has been reported that Chinese terrorist fighters that the Islamic State recruited returned and conspired to carry out terrorist attacks using the military training and even fighting experiences they received in Syria. For example, several terrorist groups which fought for the Islamic State were broken up in March 2015 in the region. ${ }^{21}$

That terrorist groups became harder to be tracked down and more connected than before, which explains why terrorist attacks in China reached a peak both in term of number and damage around 2014. As Table 1 shows, six serious terrorist attacks occurred in the first half of 2014, killing 90 and injuring hundreds of innocent citizens. What is more important, these attacks clearly showed that terrorist threat was not

20 S. H. Kang and R. E. Hu, 'Kongbuzhuyi Lishi yu Xianzhuang [History and Current Situation of Terrorism]', Legal Jurisprudence 6 (2003), 20-21.

21 T. C. Wong, 'Terrorists in Xinjiang returned from IS', December 8, 2019. Available: www.globaltimes.cn/content/911314.shtml (26. 11. 2020.) 
confined to Xinjiang any longer and has spread all over the country, from Xinjiang in the north to Kunming in the south and Guangzhou in the east, and thereby aroused intensive panic and fear in society. It is under such an enormous pressure that Chinese legislators adopted several laws and acts around 2015 targeting to strike terrorism, extremism and separatism, such as the National Security Act of P. R. C, the Counter Terrorism Act of P. R. C and the Cyber Security Law of P. R. C.

Table 1: Major Terrorist Attacks from January to July 2014 in China. Source: Y. Zhao, Studies on Counter Terrorism Criminal Law in Contemporary China, PhD Dissertation (Beijing Normal University, 2016), 78-80.

\begin{tabular}{|l|l|l|l|}
\hline \multicolumn{1}{|c|}{ Date } & \multicolumn{1}{|c|}{ Location } & \multicolumn{1}{c|}{ Attack Means } & \multicolumn{1}{c|}{ Consequence } \\
\hline 24 January, 2014 & Akesu Prefecture, Xinjiang & Explosion & $\begin{array}{l}\text { three deaths } \\
\text { two injured }\end{array}$ \\
\hline 1 March, 2014 & Wushi Country, Xinjiang & Attacks at Police Station & $\begin{array}{l}\text { eight deaths } \\
\text { four injured }\end{array}$ \\
\hline 30 April, 2014 & Train Station of Kunming, Yunnan & Violent attacks at passengers & $\begin{array}{l}31 \text { deaths } \\
141 \text { injured }\end{array}$ \\
\hline 5 May, 2014 & Train Station of Urumqi, Xinjiang & Violent attacks at passengers & $\begin{array}{l}\text { three deaths } \\
79 \text { injured }\end{array}$ \\
\hline 22 May, 2014 & Train Station of Guang Zhou & Violent attacks at passengers & six injured \\
\hline 28 July, 2014 & Urumqi, Xinjiang & Explosion & $\begin{array}{l}39 \text { deaths } \\
94 \text { injured }\end{array}$ \\
\hline
\end{tabular}

At the same time, the Ninth Amendment also brought forward precedented changes. On the one hand, it extended coverage of extant crimes and increased punishments. For example, article 5 of the Ninth Amendment added confiscation of property and criminal fine to the offence of forming, leading and participating in a terrorist organisation in article 120 of the 1997 Criminal Law; article 6 of the Amendment extended the offence of providing fund to any terrorist organisation or individual who engages in terrorism in article 120a of the same law (about funding terrorist training); article 38 of the Amendment included the conduct of refusing to provide any evidence relating to the crime of terrorist activities or the crime of extremism, as an offence of refusing to provide evidences related to espionage in article 322 of the same law; and article 40 of the Amendment provided a heavier punishment for those illegally crossing the national border (frontier) with the purpose to participate in a terrorist organisation, to accept terrorism training or to carry out any terrorist activities. On the other hand, it created five new crimes in articles $120 \mathrm{~b}$ to120f of the 1997 Criminal Law, intending to prevent radicalisation and to de-radicalise, including making preparations to commit terrorism offences (article 120b), propagating terrorism or extremism or instigating terrorist activities (120c), disrupting the implementation of law by making use of extremism (120d), forcing others to wear or adorn the dresses or symbols that propagate terrorism or extremism (120e), and illegal possession of materials that propagate terrorism or extremism (120f). 


\subsubsection{Corruption}

Corruption is considered an issue that matters the survival of both the ruling party and the state. ${ }^{22}$ China's efforts and resolution to prevent and crack down corruption can be easily seen in the continuous execution of high-level officials and the increasing number of criminal cases. For example, Kejie Cheng, former Vice President of the NPC Standing Committee, Xiaoyu Zheng, former Director of National Administration of Drugs, and Renjie Jiang, former Vice Major of Suzhou Municipal Government were all convicted of taking grafts and executed, respectively in 2000, 2007 and 2008. Meanwhile, judicial authorities have been remaining tough on prosecuting corrupt officials, as can be easily seen in the increasing number of corruption and bribery cases at first trial from 2009 to 2015 (Figure 6).

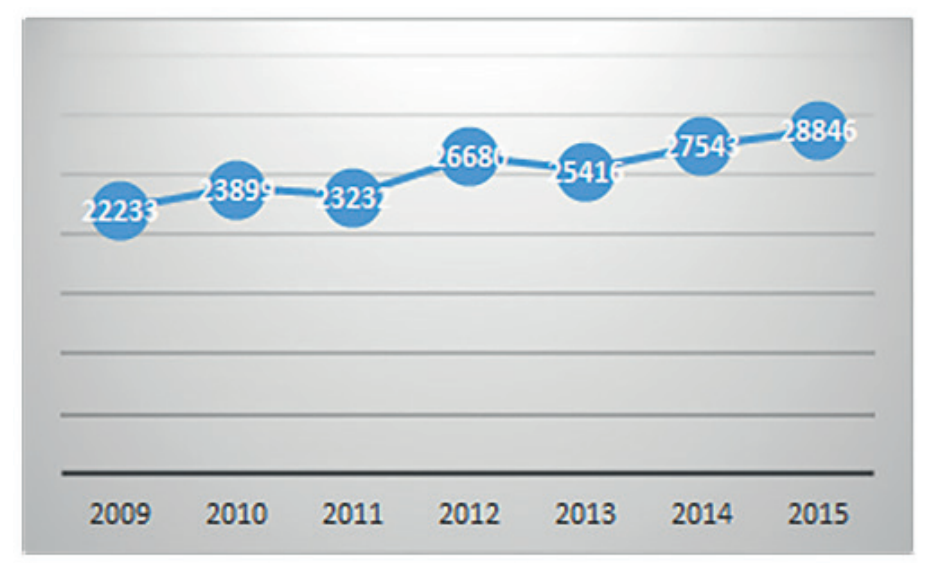

Figure 6: Number of corruption and bribery cases registered for first instance trial (2009-2015). Source: China Statistic Yearbooks (2010-2016)

Regretfully, severe and continuous strike on corruption has not turned the legislature's expectation into reality. For example, China's Corruption Perceptions Index (CPI) ranking dropped sharply from 63 in 2001 to 100 in 2014 (Figure 7) according to annual reports of International Transparency. Although it can be argued that the CPI ranking does not reflect the reality in China due to its subjective and vague assessment approaches and failure to collect public opinion in China, ${ }^{23}$ it implies, combined with heavily reported corruption cases and the number of sanctioned officials, that corruption has not been effectively prevented and may be going from bad to worse, at least in public perception. Chinese legislature carried out reforms on both substantial

22 J. Y. Zhong, 'Fanfu Changlian Shiguan Dang he Guojia Shengsi Cunwang' [Anti-Corruption and Advocation of Integrity matters Life and Death of the Part and the State], People Daily, January 30, 2013.

23 See, for example, W. Song, 'Qinglian Zhishu Lingren Nanyi Xinfu' [CPI Is Unconvincing], Procuratorial Daily, December 9, 2014. 
and procedural criminal laws to respond to public anger at the worsening corruption situation and the new practical difficulties in dealing with corruption cases caused by such factors as complicated economic structure, digitalisation of payment and internationalisation of illegal transactions.

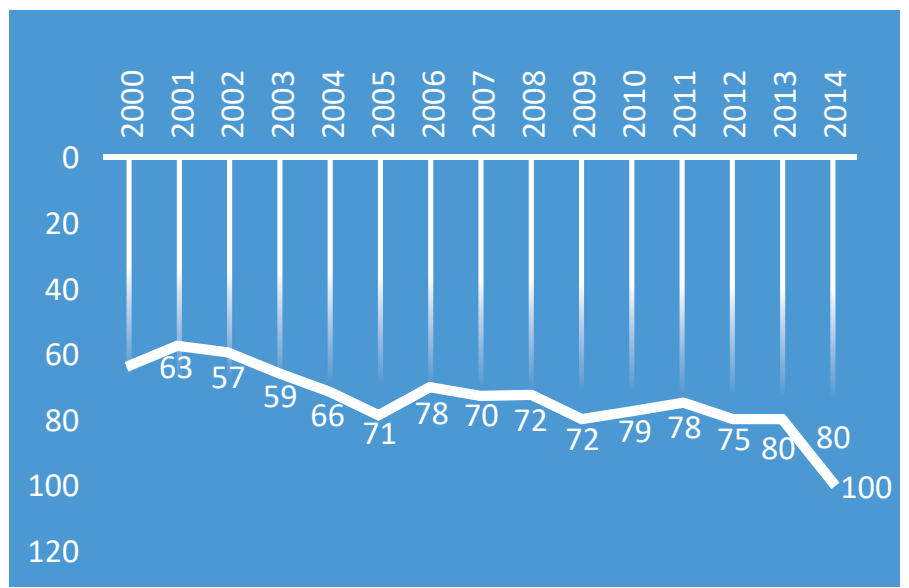

Figure 7: China's CPI ranking (2000-2014). Source: Transparency International. Available: www.transparency.lt/en/corruption-perception-index/ (08. 01. 2021.)

For example, the Sixth Amendment expanded the coverage of article 163 and article 164 of the 1997 Criminal Law from 'an employee of a company or an enterprise' to 'an employee of a company, an enterprise or other units' and thereby penalised conducts of taking grafts and offering bribes in case of all non-public organisations. Meanwhile, it categorised graft and bribery related crimes as source crime of money laundering, in article 191 of the same law. Then, the Amendment VII to the 1997 Criminal Law (the Seventh Amendment) adopted three years later created a new crime of taking bribes utilising influence of a state functionary, aiming to punish bribery crimes committed by persons in close relationship with public servants, and increased the maximum punishment for the crime of possessing property excessively larger than the legitimate income of a state functionary from five years imprisonment to ten years imprisonment. The Eighth Amendment added a clause to article 164 of the 1997 Criminal Law and thereby penalised the conduct of giving bribe to a functionary of foreign countries or an official of international public organisations for improper commercial benefit. The Ninth Amendment carried much bigger reforms than before. On the one hand, it replaced the 'pure quantitative standard' with an 'amount + circumstance' standard as the conviction threshold - the aggravating circumstance being embezzlement and taking bribes - in article 383 and article 390 of the 1997 Criminal Law. This reform gives to the people's court much wider discretion than before. On the other hand, as mentioned above, it created the Chinese version of LWOP, partly to show the public its 'zero tolerance' policy against the corruption problem and partly to realise its promise 
to gradually reduce the use of the death penalty. Moreover, it is also worth mentioning that the people's court 'must' instead of 'shall' apply criminal fine concurrently in the case of corruption as the wording of 'shall' in Chinese authorises the people's court not to impose criminal fine on corrupt officials, which was often seen in practice.

Chinese legislature also carried out reforms on procedural laws to maximise the effect of substantial criminal law reforms. ${ }^{24}$ The most meaningful one, not without any disputes and criticism over its legality and justness (see for example Deng, 2017), ${ }^{25}$ may be the newly added Confiscation Procedure for Illegal Income in Cases Where a Criminal Suspect or Defendant Escapes or Dies, by which a people's procuratorate may file an application with a people's court for confiscation of illegal income if the suspect or defendant in question escapes and cannot be present in court after being wanted for a year or dies, and his or her illegal income and other property involved in the case shall be recovered in accordance with criminal legislation.

\subsubsection{Internet}

China saw an unprecedented rapid development of internet industry in the past decade. According to China Statistical Reports on Internet Developments of 2006 to 2019, the number of Chinese netizens rose from 137 million in 2006 to 828 million in 2018 at a shocking pace (Figure 8). In other words, nearly 60 per cent of the Chinese use internet in their daily life, such as shopping, communication and paying. However, a blade has two sides. While enjoying the convenience and wealth internet brings us, we have to face the risks created in or by internet. According to a report titled Characters and Current of Cyber Crimes (2016-2018) published by China Research Institute for Judicial Big Data on November 11, 2019, the people's court tried more than 48 thousand cybercrime cases at first instance nationwide from 2016 to 2018, ${ }^{26}$ and the number is still increasing quickly. More than 40 per cent of these crimes were committed by criminal groups and 30 per cent were fraud. What is more important, 37.21 per cent of the defendants were from information transmission, computer service and software industries, and nearly 40 per cent of the defendants in cyber fraud cases knew exactly their victims' personal information.

\footnotetext{
X. M. Wang and L. L. Huang, 'Jianchafa yu Xingshisusongfa Xianjie Ruogan Wenti Yanjiu' [The Research on the Issues of the Connection between Supervision Law and Criminal Procedure Law], Legal Forum 2 (2019), 135-144.

25 X. D. Deng, 'Lihai Guanxi Ren Shiyu xia Weijingdingzui zhi Moshou' [Confiscation without Conviction from the Viewpoint of Interested Parties], Journal of Fujiang Normal University (Philosophy and Social Sciences) 4 (2017), 27-35.

${ }_{26}$ Cybercrime in the report refers to conducts that are committed using or through internet and thereby infringes on citizens' legal interests or damages computer systems.
} 


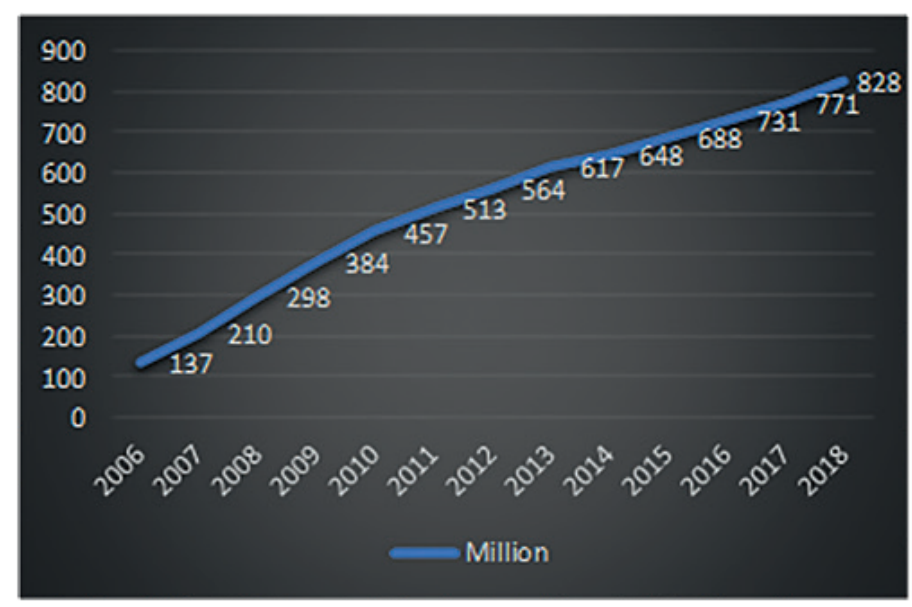

Figure 8: Number of netizens in China (2006-2018). Source: China Statistical Reports on Internet Developments (2006-2019)

The increasing threat of cyber illegality has undoubtedly been reflected in the Amendments to the 1997 Criminal Law. The 1997 Criminal Law provided only two specific crimes protecting cyber security at the time of adoption, namely, the crime of invading computer information system in article 285 and the crime of cancelling, altering, increasing or jamming functions of computer information system in article 286. Meanwhile, protection for average citizens were very weak as article 285 protected the computer information system only in the fields of state affairs, national defence construction or sophisticated science and technology, and the conviction according to article 286 required not only making the invaded system impossible to operate normally but also serious consequences. As can be imagined, the wild and disordered expansion of internet industry since the beginning of the new century, while benefitting the society, put everyone in dangers such as abusing personal information collected for legal commercial purpose. Therefore, the Seventh Amendment created three new crimes, specifically, selling or illegally providing personal information; obtaining data stored, processed or transmitted by a computer information system other than those in the fields of state affairs, national defence construction or sophisticated science and technology, or exercising illegal control over the said computer information system; and providing programs or tools specially used for intruding into or illegally controlling computer information systems.

However, the legislative reforms mentioned above were soon proven insufficient again. On one hand, restrictive constitution elements of new crimes limited their protection scope. For example, the crime of selling or illegally providing personal information in article 253 of the 1997 Criminal Law only punished staff members of a state organ or an entity in such a field as finance, telecommunications, transportation, 
education and medical treatment, but advanced internet technology has made it possible for almost everyone to commit the crime. On the other hand, to keep the society stable and safe only by public authorities becomes harder and harder, and public-private cooperation was proven indispensable. For example, removing terrorist information in cyber space is crucial to prevent terrorist recruitment and radicalisation. However, this aim cannot be achieved without effective cooperation of private organisations, especially internet giants, for at least three reasons. Firstly, public authorities may not have enough resources to check and supervise all information on internet. Secondly, it is excessively hard for them to collect enough evidences to charge and convict a defendant even if an illegal conduct were found. Thirdly, they may have difficulties in arresting, not to say charging and convicting, a suspect in a foreign country, especially where the conduct in question has not been criminalised.

Chinese legislators, responding to problems mentioned above, took more steps in the Ninth Amendment than before. For example, they eliminated restrictive constitution elements in article 253a of the 1997 Criminal Law, changing the crime to violating citizens' personal information; they penalised preparatory activities for commission of a cybercrime such as issuing any information on the production or sale of drugs, guns, obscene articles or any other prohibited article; and in article 287b of the same law, they made certain accessorial activities punishable without charging any principals, such as providing network storage or communication transmission to any person, while knowing that person is committing a crime. What is more meaningful, as mentioned above, in article 286 a of the same law they made an initial effort to facilitate public-private cooperation by penalising the failure of internet service providers to perform information network security management obligations prescribed in laws and administrative regulations, in such a case when, for example, the failure caused the spread of a large amount of illegal information.

These reforms are obliviously intended to enable criminal law to satisfy requirements of the information era for due protection, and to keep up the pace of development of internet technology by taking the legislative idea that an open crime description is better than a closed one, responding to criticism that extant legislation is insufficient to prevent and sanction dangerous activities in cyber space. The reforms are believed to be able to function well in solving problems caused by commission of traditional crimes in cyber space. ${ }^{27}$

Z. G. Yu, and S. C. W, 'Woguo Wangluo Fanzui de Fazhan jiqi Lifa Sifa Lilun Yingdui de Lishi Shuli' [Development of Cybercrime and the Historical Analysis of Its Legislative, Judicial and Theoretical Responses], Politics and Law 1 (2018), 59-79. 


\section{Adverse impacts of preventive penalisation}

Preventive penalisation has become a global phenomenon, ${ }^{28}$ partly because countries share the desire to cope with potential risks created by modern problems through the harshest tool of social control. It would be fair to say that preventive penalisation has been proven helpful in resolving practical problems in short term. However, we should also stay alert for its adverse impacts, because it may not only shake fundamental principles of modern criminal law, namely, the principle of legal interest and the principle of legality, but also turn criminal law into a meaningless symbol.

\subsection{The principle of legal interest}

It is generally believed that the task of criminal law is to protect legal interest. Therefore, crime is usually defined as conducts that harm or potentially harm a legal interest. ${ }^{29}$ Article 13 of the 1997 Criminal Law also defines crime as acts 'that endanger society' and excludes acts with clearly minor circumstances and harms that are not major. In other words, criminal law does not punish a conduct that cannot cause any harm to society at all. ${ }^{30}$ Meanwhile, criminal conviction is always accompanied by a kind of sanction, physically or psychologically, and criminal sanction, although it may function as an effective tool of retribution and prevention, is of a kind of 'evil', it should be considered and used as the last resort and should not become a choice if a legal interest could be protected in another way. However, preventive penalisation has posed a great threat to this principle.

As mentioned above, the Amendments to the 1997 Criminal Law created many crimes of conduct that do not require an actual harm for conviction. For example, according to article 120e of the law, a defendant can be held guilty if he or she forces another one to wear or adorn in a public place a dress or a symbol that propagates terrorism or extremism, no matter whether the victim is hurt or noticed or causes any disorder or not. Similarly, preparatory activities are not punishable in principle unless provided otherwise, especially in continental law countries such as Japan, ${ }^{31}$ because they can barely create a concrete risk, but the Amendments to the 1997 Criminal Law penalised several preparatory activities further as independent crimes, in order to achieve the expected deterrence. ${ }^{32}$

What is more, many articles of the Amendments to the 1997 Criminal Law may have violated the principle that criminal law is a secondary measure. In other words, they

\footnotetext{
J. H. Liu, 'Xingshi Yuancuo Anjian de Chengxufa Fenxi' [Procedural Analysis of Wrongful Convictions in China], Journal of Comparative Law 3 (2017), 24-40

29 For example A. Yamaguchi, General Part of Criminal Law (Tokyo: Yuhuikaku Press, 2007), 4.

30 M. X. Gao and K. C. Ma, Xingfaxue [Criminal Law] (Beijing: High Education Press and Law Press, 2019$), 42$.

31 K. Asada, General Part of Criminal Law (Tokyo: Seibunndo, 2007), 362.

32 Gao, 'Zhunbei'.
} 
criminalised activities that administrative and civil laws had not even sanctioned. For example, article 1 of the Amendment $V$ to the 1997 Criminal Law (the Fifth Amendment) made stealing, purchasing or illegal offering information of others' credit cards a criminal offence, but the then Ordnance on Management of Credit Card Business issued in 1996 by the People's Bank of China, the leading document regulating credit card management, and other relevant laws had not even imposed any legal responsibilities on these conducts. Such articles are obviously against the principle that criminal law should be used as the last resort. ${ }^{33}$

\subsection{The principle of legality}

The principle of legality has been accepted into almost all civilised criminal laws, although it is expressed in different ways, such as due process or the principle of legally prescribed crime and punishment. Article 3 of the 1997 Criminal Law stipulates that an act cannot be deemed as a crime unless it is explicitly provided so. The true meaning of this principle is not that it is provided in law but that it is strictly observed in practice, and preventive penalisation may have opened the Pandora box to noncompliance. For example, judged from the requirement of the principle that the description of a crime must not be vague so that abuse of power can be avoided, provisions on terrorist and extremist activities in the Ninth Amendment are especially problematic, because it does not clearly define terrorist and extremist activities.

It might be argued that article 3 of the Counter-Terrorism Act of People's Republic of China (the CTA) that became effective as of January 1, 2016 has laid down the definition of terrorism and terrorist activities. Indeed, the article defines terrorism and gives a list of terrorist activities. However, it leaves at least one back door through which any crime in the 1997 Criminal Law can be interpreted to be a terrorist one, namely, the expression 'other terrorist activities' in the last paragraph of the article. As Table 2 shows, activities listed in paragraphs (2) (4) of the article have been penalised by the 1997 Criminal Law, and paragraph (1) and paragraph (5) cover all provisions in the Special Part of the 1997 Criminal Law if the aim to realise 'political, ideological and other purposes' could be found. In practice, various conducts that have nothing to do with 'terrorism' defined in article 3 of the CTA have been punished as 'terrorist activities', such as declaring to bomb something after heavy drinking to express dissatisfaction with the government, ${ }^{34}$ causing chaos in a bus after drinking, ${ }^{35}$ and faking and telling the police that there was a bomb in a plane when driven mad by heavy life pressure. ${ }^{36}$

\footnotetext{
33 S. Liang, 'Yaoqi Xinghui Shijian Qiaoxiang Yigai Jingzhong [Pharmaceutical Enterprise Bribery Warning Medical Reforms], Xinhua Daily Telegraph August 22, 2013.

34 No. 6 First Instance Criminal Judgment (2014), Yongshu County People's Court of Sichuan Province.

35 No. 315 First Instance Criminal Judgment (2014), Dongan District People's Court of Xiamen of Fujian Province.

36 No. 168 First Instance Criminal Judgment (2015), Changning District People's Court of Shanghai.
} 
Table 2: Terrorist activities in CTA and articles in the 1997 Criminal Law. Source: compiled by the author.

\begin{tabular}{|c|l|}
\hline \multicolumn{1}{|c|}{ Terrorist Activities in article $\mathbf{3}$ of CTA } & \multicolumn{1}{c|}{ Corresponding articles in Criminal Law } \\
\hline $\begin{array}{l}\text { 1) organising, planning, preparing for, or } \\
\text { conducting activities which cause or attempt to } \\
\text { cause casualties, grave property loss, damage to } \\
\text { public facilities, disruption of social order and } \\
\text { other serious social harm }\end{array}$ & $\begin{array}{l}\text { All articles in Chapter 1 (Crimes against National } \\
\text { Security), Chapter 2 (Crimes against Public Safety), } \\
\text { Chapter 4 (Crimes against the Right of the Person } \\
\text { and Democratic Rights), Chapter 5 (Property } \\
\text { Crimes) and Chapter 6 (Crimes against Public } \\
\text { Administration) of the Special Part of the 1997 } \\
\text { Criminal Law. }\end{array}$ \\
\hline $\begin{array}{l}\text { (2) advocating terrorism, instigating terrorist } \\
\text { activities, illegally holding articles advocating } \\
\text { terrorism, or forcing other persons to wear } \\
\text { costume or symbols advocating terrorism in } \\
\text { public places }\end{array}$ & $\begin{array}{l}\text { Article 120b (Preparing for a Terrorist Activity); } \\
\text { article 120c (propagating terrorism or instigating } \\
\text { terrorist activities); article 120e (forcing others to } \\
\text { wear or adorn the dresses or symbols advocating } \\
\text { terrorism in public); 120f (knowingly and illegally } \\
\text { possessing materials advocating terrorism). }\end{array}$ \\
\hline $\begin{array}{l}\text { (3) organising, leading or participating in terrorist } \\
\text { organisations }\end{array}$ & $\begin{array}{l}\text { Article 120 (forming, leading or participating in } \\
\text { a terrorist organisation) }\end{array}$ \\
\hline $\begin{array}{l}\text { (4) providing information, funds, materials, } \\
\text { labour services, technologies, places and other } \\
\text { support, assistance and convenience to terrorist } \\
\text { organisations, terrorists, the implementation } \\
\text { of terrorist activities or training on terrorist } \\
\text { activities }\end{array}$ & $\begin{array}{l}\text { Article 120a (assisting in implementation of } \\
\text { a terrorist activity). }\end{array}$ \\
\hline $\begin{array}{l}\text { 5) other terrorist activities } \\
\text { other }\end{array}$ & $\begin{array}{l}\text { All other articles in the Special Part of the 1997 } \\
\text { Criminal Law }\end{array}$ \\
\hline
\end{tabular}

The vagueness in definitions of terrorism and terrorist activities may be more problematic when seen from article 30 of the CTA, which provides a special Settlement and Education System to rehabilitate terrorist and extremist convicts who still pose a 'social danger' after serving their sentences by organising them to participate in training and education programs. Because expressions of 'other terrorist activities' and 'other purposes' in article 3 of the CTA make the scope of terrorist crime boundless and a due application process is absent, it cannot be safely said that the Settlement and Education System will be applied properly in practice. ${ }^{37}$

\subsection{Symbolic legislation}

That the life of law does not lie in its enactment but in its enforcement is not only a common sense but also a political statement in China. ${ }^{38}$ No matter how just its adoption process is, a law that could not positively influence targeted activities and lead society to development in the right direction cannot be justified and may become

37 Z. J. Zhou, 'Anzhijiaoyu de Fazhi Fengxian yu Yufang' [Legal Risks of Settlement and Education System and Prevention Measures], Western Law Review 3 (2017), 75-84.

38 For example Q. Zheng, 'Falv de Shengming Zaiyu Shishi', Study Times, June 20, 2018. 
the so-called symbol of normative statement. ${ }^{39}$ In other words, legislators do not expect the law to effectively prevent illegal phenomena in question, and just adopt it as a symbol demonstrating their attitude towards public anger caused by the phenomena. It is regretful to say that a considerable part of China's preventive efforts in recent decades may have become such a symbol.

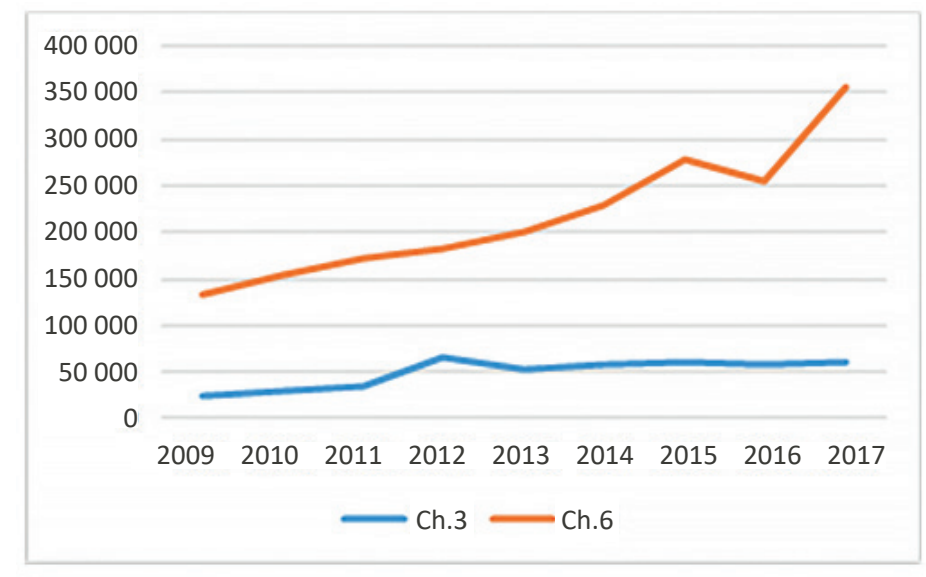

Figure 9: Criminal cases of Ch.3 and Ch.6 at first instance trial (2009-2017). Source: China Statistic Yearbooks (2010-2018)

As mentioned above, 19 newly created crimes are such that disturb the order of social administration (in Chapter 6 of Special Part of the 1997 Criminal Law) and 17 such that disturb the order of market economy (Chapter 3 of the same part). As Figure 9 shows, while the number of criminal cases of Chapter 6 at first instance trial from 2009 to 2017 was on sharp increase, that of Chapter 3 in the same period decreased, although slowly, since 2012. Judged from the fact that conducts punished by Chapter 3 such as producing and selling food with poisonous ingredients, polluting environment, and financial defraud, have been focuses of both public and political attention for so long a time, such a decrease can reasonably be considered a consequence of ineffective law enforcement. In other words, preventive efforts in Chapter 3 may be deemed symbolic. For a specific example, the Eighth Amendment criminalised the conduct of refusing to pay labour remuneration in article 276a of the law due to its violation of legitimate rights of ordinary workers and great adverse impact on socialist harmonious society. ${ }^{40}$ Then, does this effort work? The answer may be negative, because few corporations were prosecuted even in the following year, and the phenomena became even more

Liu, 'Xiangzhengxing'.

40 M. X. Gao and L. Chen, Zhonghuarenmingongheguo Xingfaxiuzhenganba Jiedu yu Sikao [Understanding Amendment VIII to the Criminal Law of the People's Republic of China] (Beijing: China Renmin University Press, 2012), 108. 
serious than before, ${ }^{41}$ just as once commented in scholarly literature: compared to the total number of 218,000 complaints involving refusal to pay labour remuneration handled by labour security supervision authorities in 2012, the number of 152 criminal cases filed at the people's court with only 134 closed in May 2011 to December 2012 is obviously 'disproportionate'. ${ }^{42}$ Another suitable example is cybercrime legislation. As mentioned above, the Ninth Amendment created four crimes to safeguard internet security. Then, how many criminal cases have been closed so far? Although zero is doubtful, it is true that no conviction report has been found in leading databases. Meanwhile, five of ten specific cybercrimes in the 1997 Criminal Law have not been used, ${ }^{43}$ and the other five have only been used in 240 cases in the 20 years of 1997 to 2017. Such a low application rate cannot convey to citizens the message that all crimes will be punished and thereby strengthen their belief in law. Nor can it help in deterring potential offenders.

Finally, it is commonly accepted that the deterrence of criminal punishment depends not only on its severity, but also on its certainty and timeliness. ${ }^{44}$ As mentioned above, corporate crime and corruption crime have been especially stressed in recent decades, and offering bribe committed by corporations is now considered one of focuses of law enforcement due to its features such as large value of bribes, long duration of bribery act and difficulties in disclosing, ${ }^{45}$ and it accounts for a big part of all kinds of cases of offering bribe. ${ }^{46}$ However, analysis of 827 corporate bribery cases closed in 2008 to December 2016 shows that more than 76 per cent of convicted natural persons are declared to be on probation, 12.6 per cent of convicted legal persons are not ordered to pay any fine, and the average amount of fine is much lower than that of bribe value. Meanwhile, the analysis finds that more than 36 per cent of bribery conducts lasts more than two years, and 17 per cent more than five years. ${ }^{47}$ It may be inferred from these facts that at least the requirements of severity and timeliness are not met in the case of corporate bribery. Then, how can we expect the law to function effectively?

Briefly, many efforts that China made to deal with risks in modern society may be deemed as symbolic legislation to a degree.

${ }^{41}$ W. J. Liu, 'Rang Jubuzhifu laodongbaochou Zui Xian Weili' [Let crime for dodging labor remuneration show its power], People's Court Daily, January 12, 2013.

42 P. F. Shu, 'Jubuzhifu Laodongbaochou Zui Yanjiu' [Study on Crime for Dodging Remuneration], Chinese Criminal Science 20 (2013), 58.

43 Liu, 'Xiangzhengxing'.

44 For example C. Beccaria, Lun Fanzui yu Xingfa [On Crime and Punishment] (Chinese Translation) (Beijing: China Encyclopedia Press, 1996), 56, 59.

45 Liang, 'Yaoqi'.

${ }^{46}$ M. C. Yin and, C. X. Gao, 'Danwei Xinghui Zui Shizheng Yanjiu' [Empirical Studies on Corporate Bribery], Legal Forum 2 (2014), 277-287.

47 Z. J. Zhou, 'Danwei Xinghui Anjian Shizheng Yanjiu' [Empirical Studies on Sentencing in Corporate Bribery Cases], Journal of Henan Policy Institute 1 (2020), 1-15. 


\section{Judicial restriction on adverse impacts of preventive penalisation}

The adverse impacts of preventive penalisation lay a heavy burden on Chinese judicial authorities to ensure that all the reforms be applied as expected in the right way. Although it should be admitted that they have made valuable efforts, typical cases show that there is a long way to go before establishment of an effective check and balance mechanism between preventive penalisation and judicial restriction.

\subsection{Legal foundation of judicial restriction and feasible choices}

Chinese Constitution, criminal law and criminal procedural law has laid down sound foundation for judicial authorities to restrict the adverse impacts of preventive penalisation in a case-by-case way.

Criminal punishment deprives citizens of their fundamental rights, including the right to life, and one of the main functions of the Constitution is to safeguard citizens' fundamental rights. Therefore, it is common to see foreign courts quoting constitutional requirements or prohibitions to justify their decisions. For example, France and South Africa abolished the death penalty depending on constitutional protection for the right to life, ${ }^{48}$ and South Korea abolished the crime of adultery in 2015, quoting its Constitutional provisions on protection for privacy and citizens' freedom to choose their partner. ${ }^{49}$ The Constitution of the People's Republic of China (hereinafter, the Constitution), as amended in 2018, provides in the preclude that the Constitution is the fundamental law and has supreme legal authority, and in article 33, that the State respects and preserves human rights. Although the authority to interpret the Constitution rests only with the NPC Standing Committee, the people's court is not prohibited from applying it in specific cases. A survey conducted in 2018 disclosed that the Constitution was quoted in about 200 cases in the past three years. For example, the SPC dismissed the appeal by confirming the plaintiff's constitutional right to education in 'Qi Yuling vs. Chen Xiaoqi' in 1991..$^{5}$ Therefore, it is both possible and feasible for a people's court to quote the Constitution to exempt those charged with conducts that causes no harm to society, although they may formally contravene criminal law, because liberty is undoubtedly one of the fundamental human rights.

In addition to provisions in the Constitution, the definition of crime in article 13 of the 1997 Criminal Law constitutes another legal foundation for judicial restriction.

48 R. Hood, and C. Hoyle, The Death Penalty: A Worldwide Perspective (Oxford: Oxford University Press, 2015), 468.

49 H. Y. Huang, 'Hanguo Shixing 62 Nian de Tongjianzui Beifeichu' [South Korea Abolished Adultery Enforced for 62 Years]. Available: http://korea.people.com.cn/n/2015/0227/c205167-8854603.html (26. 11. 2020.)

50 J. Z. Wang, 'Zhongguo Sifa Panjue zhong de Xianfa Zongying' [Footprints of the Constitution in Judicial Judgments], Sina, December 8, 2019. Available: http://news.sina.com.cn/c/2018-04-25/doc-ifzqvvsa7995977.shtml (26. 11. 2020.); J. P. Feng, 'Woguo Sifaanjue zhong de Xianfa Yuanyin jiqi Gongneng' [Constitutional Reference and Its Functions in Judicial Decisions in China], CASS Journal of Law 3 (2017), 44-60. 
According to the article, all crimes must be conducts that endanger the society, and those with especially light circumstances are not punishable. Meanwhile, article 37 of the same law authorises the people's court to exempt a defendant from criminal punishment in a case where his or her circumstances are minor. Correspondingly, article 16 and article 177 of the Criminal Procedure Law of the People's Republic of China (hereinafter, Criminal Procedure Law) authorises a prosecutor not to charge a suspect if circumstances of the alleged conduct are obviously minor, criminal punishment is unnecessary or the suspect is exempted from criminal punishment in accordance with criminal law.

Briefly, Chinese judicial authorities can choose to restrict the adverse impacts of preventive penalisation in the following ways. In the first place, the prosecution may choose not to charge a suspect if the alleged conduct did not and does not potentially cause any substantial harm to the society or the circumstances are minor. Secondly, the people's court may choose to acquit a defendant in the same case. Thirdly, the people's court may use the system of conviction without sentencing in the 1997 Criminal Law. That is, it may convict a defendant without imposing any punishment. The third choice shall really not be recommended here because criminal conviction has a special symbolic meaning as a label of stigma in China, and has been proven to be a major obstacle preventing convicts reintegrating into society smoothly. ${ }^{51}$ However, it may be a realistic one because, as correctly commented by a scholar, the train of a criminal proceeding, once started, cannot be stopped due to the complicated relationship among the police, the prosecution and the people's court. ${ }^{52}$

\subsection{Effective restriction? A long way to go}

The ability of judicial authorities to effectively restrict the adverse impacts of preventive penalisation has been proven in recent cases. For example, in the Wang Lijun Case in 2016, the defendant was convicted of illicit trade by Linhe District Court of Bayan Nur City of Inner Mongolia Autonomous Region according to an act adopted in the beginning of the 1980s - which required businesses to acquire licenses to purchase grain, in order to protect the then planned economy system -, and was sentenced to a suspended one-year imprisonment on April 15, 2016. The judgment became effective ten days later, as neither the defendant nor the people's procuratorate appealed. After heavily reported, the case was ordered to be reheard by the SPC on December 16, 2016. In February 2017, Bayan Nur City Intermediate People's Court revoked the verdict, stating that the defendant had not severely damaged market order. When selecting the case as a guiding case, the SPC clearly stated that whether a business

\footnotetext{
51 This is exactly the reason why Amendment VIII exempted those sentenced to less than five years imprisonment for a crime committed under the age of 18 from the obligation of reporting their criminal record when joining the army or seeking employment.

52 Liu, 'Xingshi'.
} 
conduct should be considered illicit trade or not depends on whether it causes social harm and gives rise to a serious disruption of the market order or not. ${ }^{33}$ Apparently, the final judgment was made depending on the second choice mentioned above.

However, it is regretful to say that more cases have shown that there is still a long way to go before a check and balance system that can ensure effective judicial restriction, because the absolute majority of judicial professionals are still reluctant to play their role as expected. For example, in the Zhao Chunhua Case in 2017, the defendant, a 51 years old Chinese woman, was arrested by Tianjin police on December 27, 2016, because of six model guns that she used in a small roadside recreational shooting gallery - which she ran to support her family from August to October 12, 2016 -, and that were identified as real guns. She then was sentenced to three and a half years imprisonment after being convicted of illegal gun possession by a district court in Tianjin. She appealed against her conviction to the First Intermediate People's Court of Tiajian. On January 1, 2017, the intermediate court, while upholding her conviction, reduced her sentence to a three-year probation, stating that she posed little threat to society. ${ }^{54}$

Although it is the Zhao Chunhua Case that triggered a public outcry and widespread debate, there had been 23 similar criminal convictions before. ${ }^{55}$ It is strongly proposed that the defendants, especially Zhao, should be acquitted, because the legal standard for defining guns issued by the Ministry of Public Security is so low that a convistion should be deemed unjust. ${ }^{56}$ Intending to defuse the 'systemic crisis' ${ }^{\text {'57 }}$ that resulted from public disaffection and legislative standard exemplified in Zhao's case, the SPC issued an Official Reply on Issues concerning Conviction and Sentencing in Criminal Cases Involving Guns Powered by Compressed Gas and Air Rifle Pellets (Interpretation No. 8 [2018], SPC) on March 3, 2018, requiring the people's court to take into consideration such circumstances as the appearance, material, launcher, purchase place and channel, price, use purpose, and injury force of the gun involved, and to ensure that the severity of the punishment is commensurate with the crime committed and the criminal liability to be borne by the offender. In other words, the final judgment on unlawfulness of a conduct must be based on a comprehensive and substantial assessment on harm or potential harm, motivation, social impact, and so on, even if it violates criminal law formally.

Although it may be argued the stance of the people's court in the Wang Lijun Case and the Zhao Chunhua Case has proven that concerns on the negative impact of preventive penalisation is unnecessary as judicial authorities could reach a reasonable

53 Notice of the Supreme People's Court on Issuing the Nineteenth Group of Guiding Cases (No. 338 [2018] of the Supreme People's Court).

54 Y. Cao and Y. N. Peng, 'Shooting gallery owner wins appeal', China Daily, December 8, 2019. Available: www.chinadaily. com.cn/kindle/2017-01/30/content_28075519.html (26. 11. 2020.)

55 T. Z. Li, 'Quanguo 23 Qi Qiqiu Baitan Sheji'an 17 Ren Huo Huanxing' [23 Shooting Gallery Cases 17 Probation]', Beijing Youth Daily, January 1, 2017.

56 For example L. Y. Han, 'Zuixingfading Shiyexia dui Kongbaizuizhuang de Zaizhuiwen' [Rethinking Blank Description of Crime from Perspective of Principle of Legality], Chinese Criminology Review 6 (2017), 21-28; Li, 'Quanguo'.

57 J. J. Yang, 'Falv de Xitongxing Weiji yu Sifa Nanti de Huajie' [Systemic Crisis of Law and Solution to Judicial Dilemmas], Oriental Law 3 (2017), 94-100. 
judgment after balancing various interests, ${ }^{58}$ it might be too optimistic and too early to draw such a conclusion. In the beginning, public outcry aroused by intensive internet exposure played a crucial role in both cases. Meanwhile, in both cases, the first instance courts, although they have the power to, did not make a legal and rational judgment themselves. Instead, they passed the problem to courts at higher levels. Finally, the intervention of the SPC played a crucial or even decisive role in both cases, either by issuing an order or an official reply. As mentioned above, there are currently 469 specific crimes in the 1997 Criminal Law and hundreds of thousands of criminal cases every year, and the conflict of formal unlawfulness and substantial unlawfulness may exit in every case. Therefore, it is impossible for every problematic case to successfully attract public and political attention and for the SPC to interfere. Therefore, an effective check and balance mechanism between preventive legislation and judicial restriction could not be established until judicial authorities share the same stance and consciously take collective steps. Unfortunately, the two cases make it clear that both are still absent.

\section{Conclusion}

Preventive penalisation is inevitable because we must face invisible and even legal risks created by modern industries. However, punishing citizens for formally unlawful conducts that barely cause any ham to society is not only unfair but also undermines the authority of law. Therefore, the adverse impacts of preventive penalisation must be cautioned and prevented, and the judiciary should undertake this task according to the principle of rule of law.

The Chinese Constitution and criminal laws give the judiciary space and choices enough to ensure that preventive legislation function properly without causing unnecessary harm to citizens and society. Unfortunately, most judicial authorities are still reluctant to use their discretion as expected. The absence of a shared stance and conscious collective action may not only shake fundamental principles of criminal law but also turn preventive efforts a useless symbol by allocating limited resources to wrong places. Therefore, it is crucial to establish a check and balance mechanism between preventive penalisation and judicial restriction in the context of risk society. This requires more political than legal efforts and therefore is beyond the coverage of this article.

\footnotetext{
58 L. J. Wu, 'Liyi Hengliang zai Xingshi Sifa Caipan zhong de Yunyong yu Fengxian Kongzhi' [Application of Balance of Interests in Criminal Cases and Control of Risks], Zhejiang Social Sciences 4 (2019), 59-63.
} 


\section{REFERENCES}

Asada, K.: General Part of Criminal Law. Tokyo, Seibunndo, 2007.

Beccaria, C.: Lun Fanzui yu Xingfa [On Crime and Punishment] (Chinese Translation). Beijing, China Encyclopedia Press, 1996.

Beck, U.: 'Cong Gongyeshehui dao Fengxianshehui' [From Industrial Society of Risk Society(Part I)]. Marxism and Reality 3 (2003), 26-45.

Cao, Y. - Peng, Y. N.: 'Shooting gallery owner wins appeal'. China Daily, December 8, 2019. Available: www.chinadaily.com.cn/kindle/2017-01/30/content_28075519.html (26. 11. 2020.)

Chen, J.: 'Shanghai Fuxi Shijian Xiangguan Gongsi Renfa 2428.5 Wan' [Company Fined 24.285 Million in Shanghai Fuxi Scandal]. Sina, December 6, 2019. Available: http://news.sina.com.cn/sf/news/201610-03/doc-ifxwkzyh4151795.shtml (26.11. 2020.)

Deng, X. D.: 'Lihai Guanxi Ren Shiyu xia Weijingdingzui zhi Moshou' [Confiscation without Conviction from the Viewpoint of Interested Parties]. Journal of Fujian Normal University (Philosophy and Social Sciences) 4 (2017), 27-35.

Feng, J. P.: 'Woguo Sifaanjue zhong de Xianfa Yuanyin jiqi Gongneng' [Constitutional Reference and Its Functions in Judicial Decisions in China]. CASS Journal of Law 3 (2017), 44-60.

'Food safety top concern in China'. Xinhua News, June 2015. Available: www.chinadaily.com.cn/ business/2015-06/19/content_21050938.htm (08. 12. 2019.)

Gao, L. L.: 'Zhunbei Shishi Kongbuhuodong Zui - Yi Yubeixingwei Shixinghua wei Shijiao de Hongguanjiegou' [Crime of Preparation for Terrorism: Macroscopic Interpretation in the Perspective of Implementation Behaviors]. Legal Forum 2 (2018), 152-161.

Gao, M. X. - Chen, L.: Zhonghuarenmingongheguo Xingfaxiuzhenganba Jiedu yu Sikao [Understanding Amendment VIII to the Criminal Law of the People's Republic of China]. Beijing, China Renmin University Press, 2012.

Gao, M. X. - Ma, K. C.: Xingfaxue [Criminal Law]. Beijing, High Education Press and Law Press, 2011.

Gao, M. X. - Ma, K. C.: Xingfaxue [Criminal Law]. Beijing, High Education Press and Law Press, 2019.

Han, L. Y.: 'Zuixingfading Shiyexia dui Kongbaizuizhuang de Zaizhuiwen' [Rethinking Blank Description of Crime from Perspective of Principle of Legality]. Chinese Criminology Review 6 (2017), 21-28.

He, R. G.: 'Yufangxing Fankongxingshilifa Sikao' [On Preventive Counter-Terrorism Criminal Legislation]. Chinese Legal Science 3 (2016), 145-163.

Hood, R. - Hoyle, C.: The Death Penalty: A Worldwide Perspective. Oxford, Oxford University Press, 2015.

$\mathrm{Hu}$, J. 'Tanwuhuiluzui Zhongshenjianjin Zhidu De Guifanjiedu yu Lilunxingsi' [Normative Interpretation and Theoretic Reflection on LWOP for Bribery and Corruption]. Journal of Southwestern University of Political Science and Law 6 (2016), 57-64.

Huang, H. Y.: 'Hanguo Shixing 62 Nian de Tongjianzui Beifeichu' [South Korea Abolished Adultery Enforced for 62 Years]. Available: http://korea.people.com.cn/n/2015/0227/c205167-8854603. html (26. 11. 2020.)

Huang, M. R.: 'Yelun Xingzhengfan de Xingzhi jiqi dui Xingzhengxingfa Dingwei De Yingxiang' [Re-discussion on the Nature of Administrative Crime and Its Influence on the Status of Administrative Criminal Law]. Modern Law Science 5 (2004), 81-87.

Kang, S. H. - Hu, R. E.: 'Kongbuzhuyi Lishi yu Xianzhuang' [History and Current Situation of Terrorism]. Legal Jurisprudence 6 (2003), 20-21.

Li, T. Z.: 'Quanguo 23 Qi Qiqiu Baitan Sheji'an 17 Ren Huo Huanxing' [23 Shooting Gallery Cases 17 Probation]. Beijing Youth Daily, January 1, 2017.

Liang, S. 'Yaoqi Xinghui Shijian Qiaoxiang Yigai Jingzhong' [Pharmaceutical Enterprise Bribery Warning Medical Reforms]. Xinhua Daily Telegraph, August 22, 2013.

Liu, J. H.: 'Xingshi Yuancuo Anjian de Chengxufa Fenxi' [Procedural Analysis of Wrongful Convictions in China]. Journal of Comparative Law 3 (2017), 24-40.

Liu, R. W. - Jiao, X. P.: 'Fengxian Xingfa de Shehui Jichu [Social Foundation of Risk Criminal Law]'. Journal China University of Political Science and Law 3 (2014), 45-56. 
Liu, W. J.: 'Rang Jubuzhifu laodongbaochou Zui Xian Weili' [Let crime for dodging labor remuneration show its power]. People's Court Daily, January 12, 2013.

Liu, Y. H.: 'Xiangzhengxing Lifa dui Xingfa Gongneng de Sunhuai' [Damage of Symbolic Legislation on Functions of Criminal Law]. Politics and Law 3 (2018), 35-49.

Mei, C. Q. - Li, J.: 'Woguo Fankong Xingfa Lifa Yufngxing Mianxiang Jianshi' [Critical Comments on China's Counter-Terrorism]. Legal Science 1 (2018), 48-58.

Pei, X. D. et alii, 'Guanyu Bali Tanwu Huilu Xingshi Anjian Ruogan Wenti de Jieshi Lijie yu Shiyong' [Understanding and Application of Interpretation on Legal Issues regarding Handling Criminal Cases of Corruption and Bribery]. People's Justice 19 (2016), 17-20.

Shu, P. F.: 'Jubuzhifu Laodongbaochou Zui Yanjiu' [Study on Crime for Dodging Remuneration]. Chinese Criminal Science 20 (2013), 15-22.

Song, W.: 'Qinglian Zhishu Lingren Nanyi Xinfu' [CPI Is Unconvincing]. Procuratorial Daily, December 9, 2014.

Wang, J. Z.: 'Zhongguo Sifa Panjue zhong de Xianfa Zongying' [Footprints of the Constitution in Judicial Judgments]. Sina, December 8, 2019. Available: http://news.sina.com.cn/c/2018-04-25/ doc-ifzqvvsa7995977.shtml (26. 11. 2020.)

Wang, W. H.: 'Jubu Lvxing Xinxi Wangluo Jianguan Yiwu Zui Shiyong Fenxi' [Analysis of the Crime of Refusing to Fulfill Network Security Management Obligation]. People's Procuratorate 6 (2016), 24-27.

Wang, X. M. - Huang, L. L.: ' Jianchafa yu Xingshisusongfa Xianjie Ruogan Wenti Yanjiu' [The Research on the Issues of the Connection between Supervision Law and Criminal Procedure Law]. Legal Forum 2 (2019), 135-144.

Wong, T. C.: 'Terrorists in Xinjiang returned from IS', December 8, 2019. Available: www.globaltimes.cn/ content/911314.shtml (26.11. 2020.)

Wu, L. J.: 'Liyi Hengliang zai Xingshi Sifa Caipan zhong de Yunyong yu Fengxian Kongzhi' [Application of Balance of Interests in Criminal Cases and Control of Risks]. Zhejiang Social Sciences 4 (2019), 59-63.

Wu, Y. H.: 'Lun Zuowei Sixing Tidai Cuoshi de Zhongshenjianjin' [LWOP as An Alternative to the Death Penalty]. Global Law Review 1 (2017), 131-148.

Yamaguchi, A.: General Part of Criminal Law. Tokyo, Yuhuikaku Press, 2007.

Yang, J. J.: 'Falv de Xitongxing Weiji yu Sifa Nanti de Huajie' [Systemic Crisis of Law and Solution to Judicial Dilemmas]. Oriental Law 3 (2017), 94-100.

Yin, M. C. - Gao, C. X.: 'Danwei Xinghui Zui Shizheng Yanjiu' [Empirical Studies on Corporate Bribery]. Legal Forum 2 (2014), 277-287.

Yu, Z. G. - W, S. C.: 'Woguo Wangluo Fanzui de Fazhan jiqi Lifa Sifa Lilun Yingdui de Lishi Shuli' [Development of Cybercrime and the Historical Analysis of Its Legislative, Judicial and Theoretical Responses]. Politics and Law 1 (2018), 59-79.

Zhao, Y.: Studies on Counter Terrorism Criminal Law in Contemporary China. PhD Dissertation, Beijing Normal University, 2016.

Zheng, Q.: 'Falv de Shengming Zaiyu Shishi' [Life of Law Lies in Its Enforcement]. Study Times, June 20, 2018.

Zhong, J. Y.: 'Fanfu Changlian Shiguan Dang he Guojia Shengsi Cunwang' [Anti-Corruption and Advocation of Integrity matters Life and Death of the Part and the State]. People Daily, January 30, 2013.

Zhou, Z. J.: 'Danwei Xinghui Anjian Shizheng Yanjiu' [Empirical Studies on Sentencing in Corporate Bribery Cases]. Journal of Henan Policy Institute 1 (2020), 1-15.

Zhou, Z. J.: 'Anzhijiaoyu de Fazhi Fengxian yu Yufang' [Legal Risks of Settlement and Education System and Prevention Measures]. Western Law Review 3 (2017), 75-84.

Zhou, Z. J.: 'Risk Society and Corporate Criminal Liability'. WIAS Research Bulletin 11 (2019), 17-30.

Zhou, Z. J.: Bijiaofa Shiye zhong de Danwei Fanzui [Comparative Studies on Corporate Crime]. Beijing: China Public Security University Press, 2012. 